\title{
The Versatile Role of microRNA-30a in Human Cancer
}

\author{
Xiang Yang ${ }^{a}$ Yitian Chen ${ }^{a, b}$ Longbang Chen ${ }^{a, b}$ \\ aDepartment of Medical Oncology, Jinling Hospital, Second Military Medical University, ${ }^{b}$ Department of \\ Medical Oncology, Jinling Hospital, School of Medicine, Nanjing University, Nanjing, China
}

\author{
Key Words \\ microRNA-30a • Cancer • Oncogene • Onco-suppressor
}

\begin{abstract}
MicroRNAs (miRNAs) are a group of noncoding RNA molecules of 20-23 nucleotides length that negatively regulate gene expressions in numerous cellular processes. Through complementary paring with target mRNAs, miRNAs have frequently emerged as dual regulators of cancer development by acting on multiple signaling pathways, thereby act as novel biomarkers for cancer diagnosis, prognosis, and prediction of response to treatment. As one of them, miR-30a has been found to act as an onco-suppressor of tumorigenesis pathways through inhibition of cellular proliferation, migration and invasion. Simultaneously, miR-30a plays a progressing role in several types of cancer, determined by relevant target genes as well. In the present review, we summarize recent research regarding miR-30a, including its biological function, expression and regulation, especially focusing on its role in cancer development and progression. Clinically, miR-30a may serve as a potential target in the diagnosis and therapy of human cancer.
\end{abstract}

C 2017 The Author(s) Published by S. Karger AG, Basel

\section{Introduction}

MiRNAs, a set of non-coding RNAs encoded by the genome with about 20-23 nucleotides in length, play important roles in various biological processes, including cellular proliferation, differentiation and apoptosis $[1,2]$. By complete or incomplete complementary paring to the 3'-untranslated region (UTR), miRNAs promote degradation or translational repression of targeted mRNAs and act as negative post-transcriptional modulators [3, 4]. Each miRNA targets approximately 200 mRNAs, while each mRNA can be targeted by couple of miRNAs [5].

Most of the genes encoding miRNA are located in fragile sites or in cancer-associated genomic region, implying that miRNAs are extensively involved in cancers [6]. In the last decade, abnormal expression of miRNAs has increasingly been documented in the progress

Y. Chen and L. Chen contributed equally to this work and share corresponding authorship. 


\section{Cellular Physiology Cell Physiol Biochem 2017;41:1616-1632 \\ \begin{tabular}{ll|l} 
and Biochemistry Published onIIne: VIarch 28, 2017 & $\begin{array}{l}\text { (c) 2017 The Author(s). Published by S. Karger AG, Basel } \\
\text { www.karger.com/cpb }\end{array}$ \\
\hline
\end{tabular} \\ Yang/Chen/Chen: MiR-30a Plays a Dual Role in Types of Human Cancer.}

of human cancer, involving oncogenesis, invasion and metastasis, functioning as oncogene or tumor suppressor [7-9]. Therefore, miRNAs have provided a promising insight into strategies of diagnosis and prognosis in various types of human cancers [10-13]. Moreover, the diagnostic and prognostic characteristics of miRNAs could open new opportunities in the field of cancer therapy [14-18].

To data, miRNA30a has been demonstrated to be involved in development of several types of tumors [19-21]. This article reviews the current research of the physiology of miR30 a with a focus on its function in different types of cancers.

\section{Biological function of miR-30a gene}

The miR-30 family consists of five highly conserved and mature members (miR-30a, $-30 b,-30 c,-30 d$ and $-30 e$ ), which lie in different chromosomes or neighboring sites (Fig. 1). Among the members, miR-30a is located on chromosome 6q13, and is derived from an intron transcriptional unit [22]. MiR-30a has usual functions of many miRNA species, and participates in a wide spread of biological processes, including cellular differentiation and development. In osteoarthritis, significantly upregulated miR-30a promoted extracellular matrix degradation by modulating Sox9 and downstream effectors [23]. In the myogenic regulatory activity, overexpression of miR-30a resulted in expanded apoptosis and altered somite morphology by controlling Sine oculis homeobox 1 (Six1) expression[24]. In mesenchymal stem cells (MSCs), miR-30a presented to be biomarker and novel regulator on the osteogenic differentiation other than proliferation by inhibiting bone morphogenetic protein $9[25,26]$. Furthermore, the over expression of miR-30a promoted chondrogenic differentiation via down-regulating the expression of Delta-like 4 (DLL4, a ligand of the Notch signaling family) [27]. In addition, miR-30a stimulates arteriolar branching by abrogating endothelial DLL4, consequently controlling endothelial tip cell behavior [28]. As demonstrated, glioma cell invasion could be boosted by miR-30a through repressing neural cell adhesion molecule (NCAM) [29].

Notably, neuronal overexpression of miR-30a resulted in decrease of brain-derived neurotrophic factor, a crucial regulator during cortical development and maturation in prefrontal cortex [30]. After stroke, miR-30a expression was significantly reduced in cortical neurons, pretending to be a biomarker for ischemic stroke in humans, furthermore prevented neural ischemic injury by down-regulating heat shock protein A5 protein expression [31,32]. Circulating miR-30a in human was highly expressed after acute myocardial infarction, acting as a potential indicator and providing a promising therapy strategy $[33,34]$. Overexpression of glucocorticoid receptor (GR) $\alpha$ induced by silencing of miR-30a could inhibit podocytic apoptosis [35].

Epithelial-to-mesenchymal transition (EMT), which is recognized to be one of the key mechanisms for inducing variability in cell populations [36], is well characterized during organogenesis [37], wound healing [38], and initiating metastasis in epithelial cancer [39, 40]. With regard to EMT, miR-30a exhibited an attenuating effect after podocyte injury by inhibiting the nuclear translocation of nuclear factor of activated T cells 3 (NFATc3) [41]. Besides, miR-30a inhibited transforming growth factor (TGF)- $\beta 1$-induced EMT and peritoneal dialysis related peritoneal fibrosis through down-regulating of snai1 [42].

Autophagy is a cellular process of self-degradation of double membrane-bound vesicles in which organelles or portions are sequestered into autophagosome for energy production [43]. Overexpression of miRNA-30a could restrain the beclin-1 expression induced by Hepatitis $\mathrm{B}$ virus $\mathrm{X}$ protein $(\mathrm{HBx})$, wherefore modulating autophagosome formation in hepatic cells [44]. Through inhibiting beclin-1, miR-30a was proved to activate autophagy during myocardial injury induced by angiotensin II [45], thereby eased pressure overloadmediated cardiomyocyte hypertrophy [46]. As demonstrated, miR-30a affected autophagy via modulating Beclin-1 expression [47], thereby played a pivotal role in rheumatoid arthritis [48] and cancer development and treatment [49].

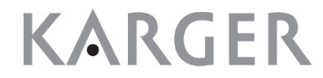


Fig. 1. Architecture of the miR-30 family. The miR-30 family members lie in different chromosomes or neighboring sites.

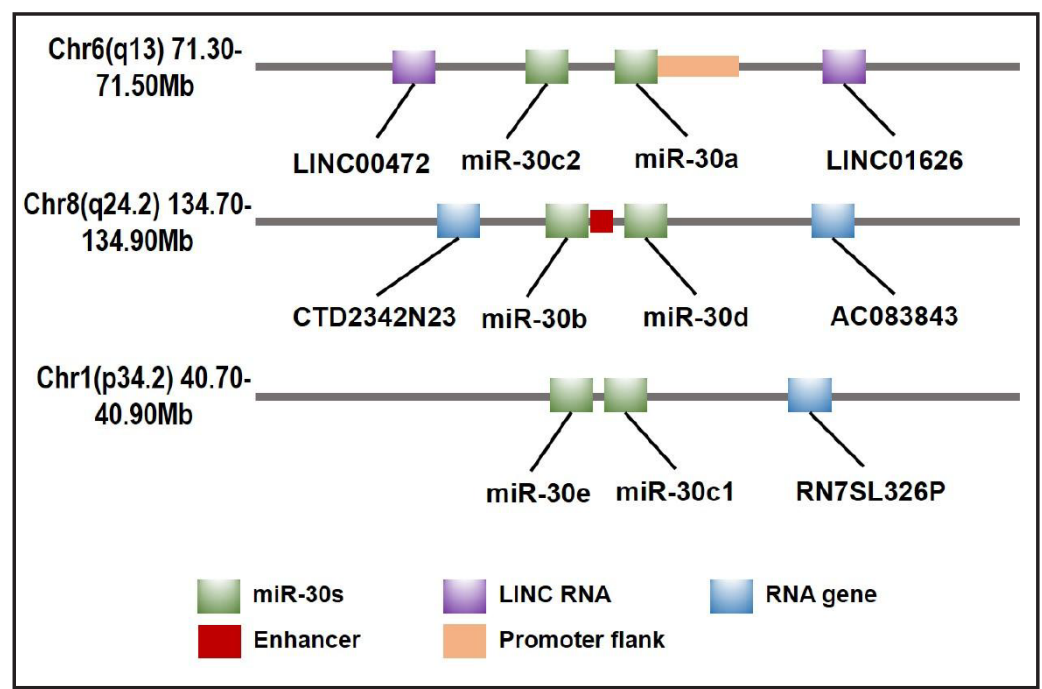

Fig. 2. Factors regulating expression of miR-30a. Expression of miR-30a is modulated in different modes.

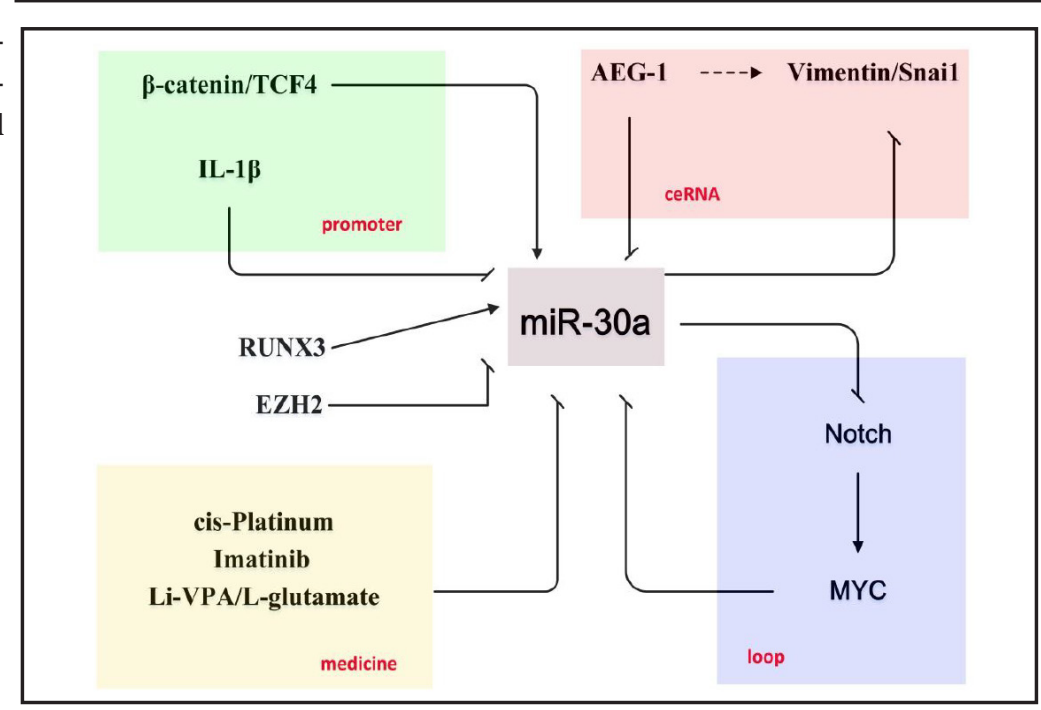

In addition, miR-30a played a crucial role in the regulation of the autoimmune responses in rheumatoid arthritis and systemic sclerosis by blocking B cell-activating factor [50]. Moreover, miR-30a could inhibit IL-10-induced cytokine release by targeting STAT1/ MD-2 (a 25kDa lipopolysaccharide-binding protein) in human monocytes [51]. Besides, miR-30a inhibited the immunosuppressive effect of IL-1 $\beta$ by targeting transforming growth factor- $\beta$-activated kinase 1 binding protein 3 (TAB3) in MSCs [52]. The level of miR-30a was much higher in systemic lupus erythematosus (SLE) patients than in healthy, which can promote B cell proliferation and the production of IgG antibodies [53]. Interestingly, an animal experiment discovered that miR-30a produced an escalation of alcohol intake and a preference over water through the brain-derived neurotrophic factor signal pathway in mouse [54].

\section{The expression regulation of $\mathrm{miR}-30 \mathrm{a}$}

Regulation of miR-30a expression occurs in several modes (Fig. 2). Accumulating evidence showed that some miRNAs have been certificated to be regulated by Wnt/ $\beta$ catenin pathway, such as let-7 and miR-371-373 cluster $[55,56]$. MiR-30a was also activated by Wnt/ $\beta$-catenin pathway through direct binding of $\beta$-catenin/TCF4 to two sites (site1:1206 to-1200; site2: -1145 to -1139) upstream of a canonical TATA-box (TATATTG) in the 
Fig. 3. The role of miR-30a in cancer. By regulating multiple targets, miR-30a participates in various of cancer processes, including proliferation, invasion, metastases and autophagy.

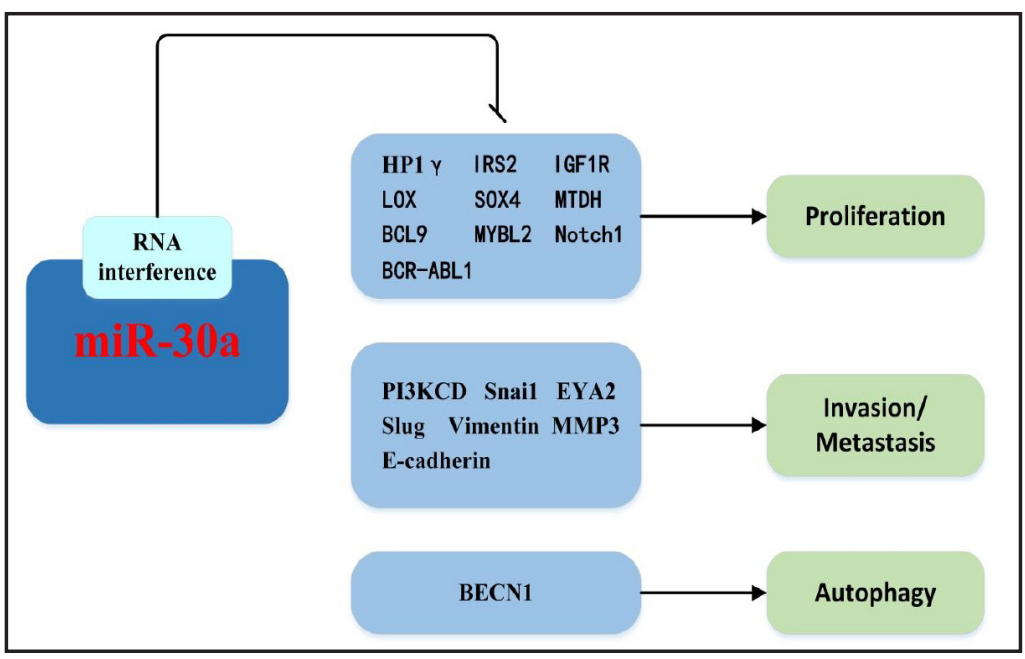

promoter region of miR-30a [29]. In human osteoarthritis, the proinflammatory cytokine interleukin-1 $\beta$ (IL-1 $\beta$ ) could suppress miR-30a expression by recruiting the activator protein (AP-1) transcription factor c-jun/c-fos to the miR-30a promoter [57]. Enhancer of zeste homolog 2 (EZH2), a critical regulator in cell survival and EMT, could inhibit miR-30a in malignant peripheral nerve heath tumor [58]. In gastric cancer cases, overexpression of RUNX3 increased the expression of miR-30a [59].

Interestingly, the expression of miR-30a was substantiated to be altered by several kind of medicines, involving lithium/valproic acid combination (Li-VPA) and L-glutamate [60], imatinib [61] and cis-Platinum [62], although the underlying mechanism was not exclusively clear.

Another regulatory mechanism underlying is competitive endogenous RNAs (ceRNA), which indicated regulating relation between messenger RNAs through competing for the shared microRNAs [63]. It was verified that the 3'-untranslated regions of AEG-1, Snai1 and Vimentin competitively bind to miR-30a in A549 cells. Accordingly, AEG-1 indirectly regulated the expression of Vimentin and Snai1 in inducing EMT of human non-small cell lung cancer (NSCLC) via competitive combining with miR-30a [64].

As already noted in other microRNAs, the expression of miR-30a is also regulated by its own targets. It was proved that miR-30a was negatively influenced by MYC [65]. Further research confirmed that miR-30a directly inhibited NOTCH expression, which induced MYC and contributed to the pathogenesis of lymphoid malignancies. Herein, a regulatory loop was characterized, where by the MYC-mediated inhibition of miR-30a suppressed NOTCH, eventually modulating its own expression [66].

\section{The role of miR-30a in human cancer}

MicroRNA mainly performs its function via interacting with target mRNA through the seed region of nucleotide sequences. As shown in Fig. 3, most of the studies involving miR30 a have paid close attention to its function in cancers, including cellular proliferation, invasion, metastasis, and autophagy. Documents have clarified that miR-30a plays a dual role as an oncogene or onco-suppressor in different types of cancers (Table 1).

\section{Expression and the clinical significance of miR-30a in cancer}

Levels of miR-30a were found to remarkably descend in most of cancer tissues compared with those in adjacent non-tumorous tissues, such as colorectal cancer [67, 68], hepatocellular carcinoma [69, 70], breast cancer [71], renal cell carcinoma [72], 
Table 1. Target genes of miR-30a verified in cancer cells

\begin{tabular}{|c|c|c|c|}
\hline Types of tumor & Target gene & Function role & ref \\
\hline \multirow[t]{6}{*}{ Colorectal cancer } & HP1 $\gamma$ & Inhibition of cell proliferation & [67] \\
\hline & DTL & $\begin{array}{l}\text { Growth inhibition, cell cycle arrest, induction of } \\
\text { apoptosis }\end{array}$ & {$[91]$} \\
\hline & PIK3CD & Inhibition of cell migration and invasion & [94] \\
\hline & BECN1 & Autophagy & [92] \\
\hline & IRS2 & Inhibition of cell proliferation, migration and invasion & [93] \\
\hline & ITGB3 & Inhibition of metastasis & {$[68]$} \\
\hline Gastric cancer & Vimentin & Inhibition of invasion and EMT & [59] \\
\hline \multirow{5}{*}{ Lung cancer } & & Onco-suppressor & [19] \\
\hline & BCL11A & Onco-suppressor & {$[85]$} \\
\hline & IGF1R & Inhibition of cell proliferation, cell cycle arrest & {$[84]$} \\
\hline & Snai1 & Inhibition of invasion and metastasis & {$[86]$} \\
\hline & $\mathrm{PI} 3 \mathrm{~K} / \mathrm{AKT}$ & Inhibition of invasion and migration & [115] \\
\hline \multirow[t]{3}{*}{ Glioma } & & Oncogene & {$[80]$} \\
\hline & SEPT7 & Oncogene & {$[101]$} \\
\hline & SOCS3 & Tumorigenecity & {$[100]$} \\
\hline Renal cell cancer & BECN1 & Autophagy & {$[72]$} \\
\hline $\begin{array}{l}\text { Chronic myelogenous } \\
\text { Leukemia }\end{array}$ & BECN1,ATG5 & Autophagy & {$[61]$} \\
\hline Chondrosarcoma & SOX 4 & Onco-suppressor & {$[73]$} \\
\hline Ewing sarcoma & & Inhibition of cell proliferation and invasion & [103] \\
\hline Anaplastic thyroid cancer & LOX & Inhibition of cell proliferation, invasion, and migration & [75] \\
\hline Ovarian cancer & & Oncogene & $\begin{array}{l}{[81, \quad 117,} \\
118]\end{array}$ \\
\hline Lymphoid malignancies & Notch & Onco-suppressor & {$[66]$} \\
\hline Giant cell tumor of bone & Runx2 & Onco-suppressor & {$[109,110]$} \\
\hline Prostate cancer & SOX 4 & Inhibition of proliferation and EMT & [79] \\
\hline \multirow[t]{3}{*}{ Hepatocellular carcinoma } & Snai1 & Inhibition of migration, invasion and EMT & [97] \\
\hline & MTDH & Inhibition of proliferation, induction of apoptosis & [98] \\
\hline & $\begin{array}{l}\text { Vimentin, } \\
\text { MMP3 }\end{array}$ & Inhibition of proliferation, invasion and metastasis & {$[70]$} \\
\hline Multiple myeloma & BCL9 & $\begin{array}{l}\text { Inhibition of cellular proliferation, migration and drug } \\
\text { resistance }\end{array}$ & [111] \\
\hline \multirow[t]{4}{*}{ Breast cancer } & EYA2 & Inhibition of migration and invasion & [88] \\
\hline & MTDH & Inhibition of proliferation and metastasis & {$[21]$} \\
\hline & $\begin{array}{l}\text { Vimentin } \\
\text { Slug }\end{array}$ & $\begin{array}{l}\text { Inhibition of invasion and metastasis } \\
\text { Inhibition of metastasis and EMT }\end{array}$ & {$[90]$} \\
\hline & & Onco-suppressor & [71] \\
\hline Acute myeloid leukemia & MYBL2 & Inhibition of proliferation and maturation & {$[104]$} \\
\hline Chronic myeloid leukemia & BCR-ABL1 & Inhibition of proliferation & [105] \\
\hline Nasopharyngeal carcinoma & E-cadherin & Promotion of invasion and metastasis & {$[106,107]$} \\
\hline $\begin{array}{l}\text { Urothelial carcinoma of } \\
\text { bladder }\end{array}$ & Notch1 & Inhibition of proliferation, migration and invasion & {$[76]$} \\
\hline
\end{tabular}

chondrosarcoma [73], ovarian papillary serous carcinoma [74], and anaplastic thyroid cancer [75]. Furthermore, miR-30a expression decreased in patients with shorter overall survival and disease-free survival time in patients with NSCLC [19] and urothelial carcinoma of bladder [76], consistent with the lower expression of miR-30a in tumor tissues compared to their non-tumor lung tissues. In ovarian papillary serous carcinoma, miR-30a was remarkably negatively related with the grade, and was predicted to be an early detection and therapeutic approach, especially in high-grade cases [74]. Besides, miR-30a was significantly downregulated in the chemoresistant tissues of patients with advanced gastric cancer [77, 78].

However, miR-30a was indicated to significantly overexpressed in several types of cancers, whereby it presented to be an onco-suppressor. As demonstrated, miR-30a was 


\section{Cellular Physiology Cell Physiol Biochem 2017;41:1616-1632

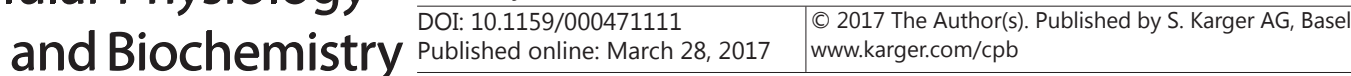 \\ Yang/Chen/Chen: MiR-30a Plays a Dual Role in Types of Human Cancer.}

upregulated by metformin and consequently significantly inhibited proliferation and EMT of prostate cancer cells[79]. In glioma, miR-30a was overexpressed in cell lines and glioma samples, and its expression level is positively correlated with tumor grade of malignancy [80]. The upregulation of urinary miR-30a was intimately associated with early stage of ovarian serous adenocarcinoma as well as lymphatic metastasis, followed by a reduction after the surgical removal of ovarian serous adenocarcinoma [81].

\section{Activities of miR-30a in cancer progression}

\section{Lung Cancer}

Lung cancer is the leading cause of tumor mortality worldwide $[82,83]$. Lung cancer is not a unique condition, but indeed a group of diseases: small cell lung cancer and non-small cell lung cancer. In NSCLC, decreased expression of miR-30a facilitated cell proliferation, G1/S, S/G2 transition through PI3K/AKT signaling pathway by targeting insulin like growth factor 1 receptor (IGF1R) [84]. Moreover, miR-30a directly targeted B-cell lymphoma/ leukemia 11A (BCL11A), an independent prognostic factor for disease-free survival and overall survival [85]. Besides, miR-30a was reported to suppress in vivo distant metastasis to the lungs and liver by targeting Snai1 in NSCLC [86].

\section{Breast cancer}

Breast cancer is one of the most common types of malignancies and the second leading cause of cancer death among females [87]. In breast cancer patients, miR-30a expression was downregulated and negatively correlated with Eye absent protein 2 (Eya2), a promoter of cell proliferation and migration [88]. Besides, miR-30a inhibited breast cancer proliferation and metastasis by directly regulating metadherin (MTDH), and served as a prognostic marker for breast cancer [21]. By downmodulating vimentin, miR-30a inhibited breast cancer invasiveness and metastasis and was associated with the outcome [89]. The tumorsuppressive function of miR-30a reversed EMT in breast cancer by directly inhibiting Slug, a member of the Snai1 family [90].

\section{Colorectal cancer}

Colorectal cancer (CRC) is one of the most prevalent carcinoma of digestive system and the third leading cause of cancer-related deaths in Western countries. MiR-30a arrested cell proliferation of colorectal cancer via downregulating protein levels of heterochromatin protein (HP1 $\gamma$ ) [67]. Meanwhile, miR-30a was identified to be onco-suppressor in colon cancer cells by down-modulating of denticleless protein homolog (DTL) which was found to be overexpressed in $95.8 \%$ of human colorectal cancers [91]. Another research found that miR-30a attenuated in CRC tissues which was correlated with higher level of Beclin-1 and autophagy [92]. Taking insulin receptor substrate 2 (IRS2) as another target gene, miR30 a suppressed phosphorylation of Akt and colon cancer cell growth [93]. Extraordinary downregulation of miR-30a in metastatic CRC tissues was found to be inversely correlated with phosphoinositide 3-kinase catalytic subunit delta (PIK3CD), which dramatically assisted cell migration and invasion [94]. By targeting integrin $\beta 3$ (ITGB3), miR-30a inhibited the migratory and invasive abilities and EMT of colorectal cancer cells, thereby suppressed cancer metastasis [68].

\section{Gastric cancer}

Gastric cancer is one of the most common malignant tumors and ranks the second most deadly cancer worldwide [95]. Invasion and metastasis of gastric cancer are considered to be the most ordinary cause of the death from the tumor [96]. Via modulating EMT, miR-30a was observed to increase cisplatin sensitivity of gastric cancer cells [78]. Positively mediated by RUNX3, miR-30a directly targeted the 3' untranslated region of vimentin and inhibited cell invasion and EMT in gastric cancer patients [59]. 


\section{Cellular Physiology Cell Physiol Biochem 2017;41:1616-1632 \\ \begin{tabular}{ll|l} 
DOI: 10.1159/000471111 & Ond 2017 The Author(s). Published by S. Karger AG, Basel \\
www.karger.com/cpb
\end{tabular} \\ Yang/Chen/Chen: MiR-30a Plays a Dual Role in Types of Human Cancer.}

\section{Hepatocellular carcinoma}

Hepatocellular carcinoma (HCC) is one of the most prevalent cancers and frequent causes of cancer leading death [87]. MiR-30a was positively correlated with worse diseasefree survival (DFS) of HCC patients, while its downregulation promoted cancer cell migration, invasion and EMT [97]. By directly targeting metadherin (MTDH), miR-30a inhibited liver cancer cell proliferation and promoted apoptosis as a onco-suppressor through PTEN/ AKT pathway [98]. Further study demonstrated that miR-30a regulated HCC cellular proliferation, invasion and metastasis by a mechanism involving reduction of vimentin and MMP3 expression and restoration of E-cadherin expression [70].

\section{Glioma}

Glioma is the most prevalent human intracranial tumor with high aggressiveness and poor prognosis [99]. Several studies have demonstrated that mir-30a served as an oncogene in glioma. In the glioma stem cells (GSCs), the overexpression of miR-30 decreased the expression of suppressor of cytokine signaling 3 (SOCS3), thereby facilitated Janus kinase/ signal transducer and activator of transcription (Jak/STAT3) pathway and downstream effect of tumorigenecity [100]. Meanwhile, overexpression of miR-30a was clarified to upgrade cell growth and invasion through the repression of (SEPT7) [101].

\section{Sarcoma}

Cartilage tumors are the most common primary bone lesions, which range from benign infirmities, such as enchondromas and osteochondromas, to malignant chondrosarcoma [102]. Clinically, miR-30a expression in chondrosarcoma cases was negatively correlated with sex-determining region Y-box 4 (SOX4), which acted as an unfavorable independent prognostic factor for patients with low histological grade [73]. In Ewing sarcoma, miR-30a decreased cell proliferation and invasion, and constituted a major functional link between EWS-FLI1 and CD99, two critical biomarkers and therapeutic targets [103].

\section{Myeloid leukemia}

In acute myeloid leukemia, low expression of miR-30a was associated with overexpression of MYB proto-oncogene like 2 (MYBL2), a transcription factor implicated in cell proliferation and maturation [104]. In chronic myeloid leukemia (CML), miR-30a reduced ABL1 and BCRABL1 protein expression, and acted as an onco-suppressor via inhibition of cell proliferation [105].

Other types of cancer

To data, miR-30a has been confirmed to participate in progression of several other cancers via regulating different targets. As demonstrated, miR-30a could inhibit cell proliferation, migration and invasion, by antagonizing oncogene Notch1 in invasive urothelial carcinoma of bladder [76]. Through promoting invasiveness and metastasis, miR-30a was identified to play an important role in Nasopharyngeal carcinoma (NPC) by directly binding to E-cadherin [106]. Furthermore, Insulin-like growth factor I (IGF-I) could induce EMT of NPC through IGF-IR-Src-miR-30a-E-cadherin pathway [107]. MiR-30a played a critical functional role in inhibiting LOX expression and thyroid cancer progression, including cell proliferation, invasion, and migration [75]. By targeting osteogenesis transcription factor runt-related transcription factor 2 (RUNX2), miR-30a stimulated adipogenesis during the development of adipocyte [108], influenced the osteoclast differentiation and osteolysis formation [109], and inhibited apoptosis [110] in giant cell tumor of bone. Evidence was presented that miR30a downregulation improved expression of BCL9, a transcriptional coactivator of the Wnt/ $\beta$-catenin signaling known to enhance multiple myeloma cell proliferation, migration, drug resistance, and formation of cancer stem cell [111].

\section{Role in chemo-resistance}

Chemo-resistance has frequently emerged to be the obstacle to chemo-therapy, retarding successful long-term survival. MiRNAs have been implicated in the chemo-resistance of 


\section{Cellular Physiology Cell Physiol Biochem 2017;41:1616-1632

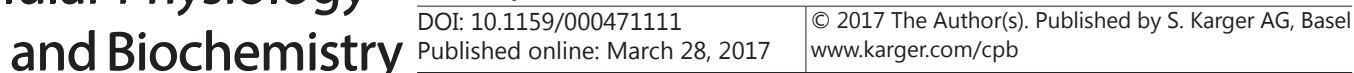 \\ Yang/Chen/Chen: MiR-30a Plays a Dual Role in Types of Human Cancer.}

numerous cancers $[112,113]$. As investigated, miR-30a decreased in bromocriptine-resistant prolactinoma compared with bromocriptine-sensitive prolactinoma [114]. Downregulation of miR-30a in renal cell carcinoma could abolish sorafenib-mediated apoptosis by an autophagy-dependent pathway induced by Beclin-1 [72]. In NSCLC, miR-30a was reported to play vital roles in overcoming the acquired resistance to epidermal growth factor receptor tyrosine kinase inhibitors (EGFR-TKIs) through regulating PI3K/AKT signaling pathway [115]. Up-regulated protein translation of BECN1 and autophagy associated gene 5 (ATG5) mediated by repressed expression of miR-30a promoted autophagy in CML [116], thus improved survival of CML primary stem cells and resistance to imatinib, a selective inhibitor for certain type III [61].

However, the expression levels of miR-30a in ovarian cancer chemotherapy-resistant cell lines were significantly higher than those in chemotherapy-sensitive cell lines, which was associated with ovarian cancer chemotherapy resistance [117]. Furthermore, depletion of miR-30a in the paclitaxel-resistant ovarian cancer cells increased paclitaxel sensitivity [118].

The role of other members of miR-30 family in human cancer

Emerging evidence demonstrates that miR-30a is not the only member of miR-30 family participating in cancer progression. Documents have been accumulated to investigate the expression and role of other members of miR-30 family in human cancers [119123]. As shown in Table 2, miR-30 family members were involved in processes of cancer development, concluding proliferation, migration, invasion, EMT, metastasis, autophagy and apoptosis through distinguished targets [124-126]. Clinically, they could be useful prognostic predictors or therapeutic targets for types of cancer [127-132], or even more impacted drug sensitivity of chemotherapy [133-136].

\section{Conclusion}

Accumulating evidence has shown that aberrant expressions of miRNAs, acting as critical regulators in carcinogenesis and cancer development, prevail in many types of malignant diseases. Dysregulation of miRNA expression appears to open new opportunities in the field of diagnosis and prognosis in various cancers as a promising biomarker. MiR-30a, one of the miRNAs dysregulated in various types of cancers, has been documented to play versatile roles in pathophysiologic processes of oncogenesis, including cellular proliferation, invasion, migration and metastasis. It is now clear that dysregulation of miR-30a may interfere with the effectiveness of chemo-therapy mediated apoptosis by an autophagy-dependent pathway in prolactinoma, renal cell carcinoma, CML and ovarian cancer. Accordingly, miR30 a restores the sensitivity of cancer cells to chemo-therapy and represents to be a unique potential therapeutic target in cancer therapy. However, its significance is needed to be further evaluated in other types of cancer.

Nevertheless, research results uncovering the definite functions of miR-30a in different cancer types are inconsistent, which requires further study to specify the underlying mechanism. Downregulated miR-30a in cancer cells could function as an onco-suppressor by restraining oncogenes, alternatively overexpressed miR-30a could function as an oncogene by negatively regulating anti-oncogenes. Therefore, better understanding of gene networks regulated by miR-30a and downstream pathways may disclosure potential functions of miR$30 \mathrm{a}$ in regards to cancer diagnostics and therapeutics. Further studies should be conducted to establish panels of target genes distinct to each cancer type, taking into account cancer progression and response to treatment. Additionally, efforts should be made to disclose how the multiple signaling molecules collaborate through cross talk interactions to reveal the distinct role of miR-30a.

In summary, miR-30a is predicted to be a potential biomarker and provides a novel insight into diagnostic and therapeutic applications in human cancer. Undoubtedly, future 
Table 2. Targets of other members of miR-30 family in human cancers

\begin{tabular}{|c|c|c|c|c|}
\hline Member & Cancer types & Target gene & Function role & ref \\
\hline \multirow[t]{14}{*}{ miR-30b } & \multirow[t]{2}{*}{ NSCLC } & Cthrc1 & Inhibition of invasion and migration & [137] \\
\hline & & Rab18 & Inhibition of proliferation & [138] \\
\hline & \multirow[t]{2}{*}{ Hepatocellular carcinoma } & \multirow[t]{2}{*}{ P53 } & Induction of apoptosis, cell cycle arrest & [139] \\
\hline & & & Inhibition of EMT and metastasis & [140] \\
\hline & Prostate cancer & AR & & [141] \\
\hline & \multirow[t]{3}{*}{ Gastric cancer } & EIF5A2 & Inhibition of invasion and migration & [142] \\
\hline & & PAI-1 & Induction of apoptosis & [143] \\
\hline & & & Inhibition of migration & [144] \\
\hline & \multirow[t]{2}{*}{ Colorectal cancer } & SIX1 & Inhibition of invasion and migration & [145] \\
\hline & & KRAS, PIK3CD, BCL2 & $\begin{array}{l}\text { Induction of apoptosis, cell cycle arrest, } \\
\text { inhibition of proliferation }\end{array}$ & [127] \\
\hline & Laryngeal carcinoma & P53 & Induction of apoptosis & [146] \\
\hline & Glioma & Caspase-3, TAp63 & $\begin{array}{l}\text { Impairment of TRAIL-dependent } \\
\text { apoptosis }\end{array}$ & [147] \\
\hline & Breast cancer & Cyclin E2 & $\begin{array}{l}\text { Inhibition of proliferation, cell cycle } \\
\text { arrest }\end{array}$ & [148] \\
\hline & Melanoma & GalNAc transferases & $\begin{array}{l}\text { Induction of invasion, } \\
\text { immunosuppression }\end{array}$ & [149] \\
\hline \multirow[t]{5}{*}{ miR-30c } & \multirow[t]{2}{*}{ NSCLC } & \multirow[t]{2}{*}{ Rab18 } & Inhibition of proliferation & [138] \\
\hline & & & Induction of invasion and EMT & [150] \\
\hline & Glioma & Caspase-3, TAp63 & $\begin{array}{l}\text { Impairment of TRAIL-dependent } \\
\text { apoptosis }\end{array}$ & [147] \\
\hline & SCC of the vulva & & HMGA2 & [151] \\
\hline & Breast cancer & NOV/CCN3 & Induction of invasion & {$[152]$} \\
\hline \multirow[t]{12}{*}{ miR-30d } & NSCLC & Cyclin E2 & $\begin{array}{l}\text { Inhibition of proliferation, cell cycle } \\
\text { arrest }\end{array}$ & [153] \\
\hline & Hepatocellular carcinoma & Galphai2 & Enhancement of migration and invasion & [154] \\
\hline & \multirow[t]{3}{*}{ Prostate Cancer } & Bmi-1 & Inhibition of proliferation & [155] \\
\hline & & Socs1 & $\begin{array}{l}\text { Enhancement of proliferation and } \\
\text { invasion }\end{array}$ & [156] \\
\hline & & AR & & [141] \\
\hline & Ovarian cancer & Snail & Inhibition of EMT & $\begin{array}{l}{[157,} \\
158]\end{array}$ \\
\hline & \multirow[t]{2}{*}{ Renal carcinoma } & Cyclin E2 & Inhibition of proliferation & [159] \\
\hline & & Metadherin & Induction of apoptosis & [160] \\
\hline & \multirow[t]{2}{*}{$\begin{array}{l}\text { Anaplastic thyroid } \\
\text { carcinoma }\end{array}$} & Beclin-1 & Inhibition of autophagy & [134] \\
\hline & & $\mathrm{EZH} 2$ & $\begin{array}{l}\text { Inhibition of proliferation and colony } \\
\text { formation }\end{array}$ & [161] \\
\hline & Melanoma & GalNAc transferases & $\begin{array}{l}\text { Induction of invasion, } \\
\text { immunosuppression }\end{array}$ & [149] \\
\hline & $\begin{array}{l}\text { Malignant peripheral nerve } \\
\text { sheath tumour }\end{array}$ & KPNB1 & Induction of apoptosis & [162] \\
\hline \multirow[t]{9}{*}{ miR-30e } & Lung carcinoma & HOXA1 & Inhibition of proliferation and migration, & [136] \\
\hline & Glioblastoma & $\begin{array}{l}\text { Beclin-1, AVEN and } \\
\text { BIRC6 }\end{array}$ & $\begin{array}{l}\text { Inhibition of autophagy, induction of } \\
\text { apoptosis }\end{array}$ & [163] \\
\hline & \multirow[t]{2}{*}{ Glioma } & CBL-B & Enhancement of invasion & [164] \\
\hline & & I $\mathrm{B} \alpha$ & Induction of invasion & [165] \\
\hline & Gastric cancer & $\operatorname{Atg} 5$ & Inhibition of autophagy & [166] \\
\hline & Gastrointestinal cancer & Bmi1 & Inhibition of invasion, and metastasis & [167] \\
\hline & Hepatocellular carcinoma & P4HA1 & Inhibition of proliferation & [168] \\
\hline & Colon carcinoma & $\begin{array}{l}\text { caspase-3, } \\
\text { p21WAF1/CIP1 }\end{array}$ & $\begin{array}{l}\text { Regulation of DNA damage-induced } \\
\text { stress responses }\end{array}$ & [169] \\
\hline & CML & BCR-ABL & Induction of apoptosis & [133] \\
\hline
\end{tabular}

innovative approaches will assist our ongoing molecular exploration and clinical strategy in this field.

\section{Acknowledgments}

This study was supported by grants from the National Natural Science Foundation of China [grant number 81402492]

\section{Disclosure Statement}

All of the authors have not any conflict of interests. 


\section{Cellular Physiology Cell Physiol Biochem 2017;41:1616-1632 \begin{tabular}{l|l} 
and Biochemistry Published onIIne: IVIarch 28, 2017 & $\begin{array}{l}\text { (c) } 2017 \text { The Author(s). Published by S. Karger AG, Basel } \\
\text { www.karger.com/cpb }\end{array}$
\end{tabular}}

Yang/Chen/Chen: MiR-30a Plays a Dual Role in Types of Human Cancer.

\section{References}

1 Yates LA, Norbury CJ, Gilbert RJ: The long and short of microRNA. Cell 2013;153:516-519.

2 Hwang HW, Mendell JT: MicroRNAs in cell proliferation, cell death, and tumorigenesis. Br J Cancer 2007;96:R40-44.

- Kim VN, Han J, Siomi MC: Biogenesis of small RNAs in animals. Nat Rev Mol Cell Biol 2009;10:126-139.

4 Li C, Gao Y, Zhang K, Chen J, Han S, Feng B, Wang R, Chen L: Multiple Roles of MicroRNA-100 in Human Cancer and its Therapeutic Potential. Cell Physiol Biochem 2015;37:2143-2159.

-5 Dalmay T: Mechanism of miRNA-mediated repression of mRNA translation. Essays Biochem 2013;54:2938.

-6 Calin GA, Sevignani C, Dumitru CD, Hyslop T, Noch E, Yendamuri S, Shimizu M, Rattan S, Bullrich F, Negrini M, Croce CM: Human microRNA genes are frequently located at fragile sites and genomic regions involved in cancers. Proc Natl Acad Sci USA 2004;101:2999-3004.

-7 Ge YZ, Xin H, Lu TZ, Xu Z, Yu P, Zhao YC, Li MH, Zhao Y, Zhong B, Xu X, Zhou LH, Wu R, Xu LW, Wu JP, Li WC, Zhu JG, Jia RP: MicroRNA expression profiles predict clinical phenotypes and prognosis in chromophobe renal cell carcinoma. Sci Rep 2015;5:10328.

8 Huang CT, Oyang YJ, Huang HC, Juan HF: MicroRNA-mediated networks underlie immune response regulation in papillary thyroid carcinoma. Sci Rep 2014;4:6495.

-9 Calin GA, Croce CM: MicroRNA signatures in human cancers. Nat Rev Cancer 2006;6:857-866.

10 Del Vescovo V, Denti MA: microRNA and Lung Cancer. Adv Exp Med Biol 2015;889:153-177.

11 Gao Y, Feng B, Han S, Lu L, Chen Y, Chu X, Wang R, Chen L: MicroRNA-129 in Human Cancers: from Tumorigenesis to Clinical Treatment. Cell Physiol Biochem 2016;39:2186-2202.

12 Gao Y, Feng B, Han S, Zhang K, Chen J, Li C, Wang R, Chen L: The Roles of MicroRNA-141 in Human Cancers: From Diagnosis to Treatment. Cell Physiol Biochem 2016;38:427-448.

13 Shao Y, Geng Y, Gu W, Huang J, Pei H, Jiang J: Prognostic role of tissue and circulating microRNA-200c in malignant tumors: a systematic review and meta-analysis. Cell Physiol Biochem 2015;35:1188-1200.

14 Long W, Zhao C, Ji C, Ding H, Cui Y, Guo X, Shen R, Liu J: Characterization of serum microRNAs profile of PCOS and identification of novel non-invasive biomarkers. Cell Physiol Biochem 2014;33:1304-1315.

15 Ladeiro Y, Couchy G, Balabaud C, Bioulac-Sage P, Pelletier L, Rebouissou S, Zucman-Rossi J: MicroRNA profiling in hepatocellular tumors is associated with clinical features and oncogene/tumor suppressor gene mutations. Hepatology 2008;47:1955-1963.

16 Farazi TA, Hoell JI, Morozov P, Tuschl T: MicroRNAs in human cancer. Adv Exp Med Biol 2013;774:1-20.

17 Lu J, Getz G, Miska EA, Alvarez-Saavedra E, Lamb J, Peck D, Sweet-Cordero A, Ebert BL, Mak RH, Ferrando AA, Downing JR, Jacks T, Horvitz HR, Golub TR: MicroRNA expression profiles classify human cancers. Nature 2005;435:834-838.

18 Wang QX, Zhu YQ Zhang H, Xiao J: Altered MiRNA expression in gastric cancer: a systematic review and meta-analysis. Cell Physiol Biochem 2015;35:933-944.

19 Tang R, Liang L, Luo D, Feng Z, Huang Q He R, Gan T, Yang L, Chen G: Downregulation of MiR-30a is Associated with Poor Prognosis in Lung Cancer. Med Sci Monit 2015;21:2514-2520.

20 Xu R, Liu S, Chen H, Lao L: MicroRNA-30a downregulation contributes to chemoresistance of osteosarcoma cells through activating Beclin-1-mediated autophagy. Oncol Rep 2016;35:1757-1763.

-21 Zhang N, Wang X, Huo Q, Sun M, Cai C, Liu Z, Hu G, Yang Q: MicroRNA-30a suppresses breast tumor growth and metastasis by targeting metadherin. Oncogene 2014;33:3119-3128.

-22 Rodriguez A, Griffiths-Jones S, Ashurst JL, Bradley A: Identification of mammalian microRNA host genes and transcription units. Genome Res 2004;14:1902-1910.

23 Chang T, Xie J, Li H, Li D, Liu P, Hu Y: MicroRNA-30a promotes extracellular matrix degradation in articular cartilage via downregulation of Sox9. Cell Prolif 2016;49:207-218.

24 O'Brien JH, Hernandez-Lagunas L, Artinger KB, Ford HL: MicroRNA-30a regulates zebrafish myogenesis through targeting the transcription factor Six1. J Cell Sci 2014;127:2291-2301.

25 Zhang R, Weng Y, Li B, Jiang Y, Yan S, He F, Chen X, Deng F, Wang J, Shi Q: BMP9-induced osteogenic differentiation is partially inhibited by miR-30a in the mesenchymal stem cell line C3H10T1/2. J Mol Histol 2015;46:399-407. 


\section{Cellular Physiology Cell Physiol Biochem 2017;41:1616-1632

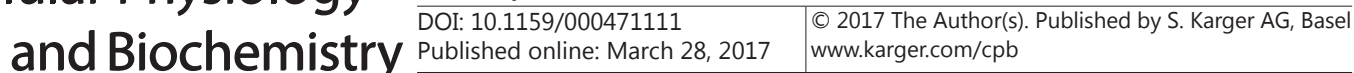

26 Eguchi T, Watanabe K, Hara ES, Ono M, Kuboki T, Calderwood SK: OstemiR: a novel panel of microRNA biomarkers in osteoblastic and osteocytic differentiation from mesencymal stem cells. PLoS One 2013;8:e58796.

27 Tian Y, Guo R, Shi B, Chen L, Yang L, Fu Q: MicroRNA-30a promotes chondrogenic differentiation of mesenchymal stem cells through inhibiting Delta-like 4 expression. Life Sci 2016;148:220-228.

28 Jiang Q, Lagos-Quintana M, Liu D, Shi Y, Helker C, Herzog W, le Noble F: miR-30a regulates endothelial tip cell formation and arteriolar branching. Hypertension 2013;62:592-598.

29 Wang Z, Dai X, Chen Y, Sun C, Zhu Q, Zhao H, Liu G, Huang Q, Lan Q: MiR-30a-5p is induced by Wnt/betacatenin pathway and promotes glioma cell invasion by repressing NCAM. Biochem Biophys Res Commun 2015;465:374-380.

-30 Mellios N, Huang HS, Grigorenko A, Rogaev E, Akbarian S: A set of differentially expressed miRNAs, including miR-30a-5p, act as post-transcriptional inhibitors of BDNF in prefrontal cortex. Hum Mol Genet 2008; 17:3030-3042.

-31 Wang P, Zhang N, Liang J, Li J, Han S, Li J: Micro-RNA-30a regulates ischemia-induced cell death by targeting heat shock protein HSPA5 in primary cultured cortical neurons and mouse brain after stroke. J Neurosci Res 2015;93:1756-1768.

- 32 Long G, Wang F, Li H, Yin Z, Sandip C, Lou Y, Wang Y, Chen C, Wang DW: Circulating miR-30a, miR-126 and let-7b as biomarker for ischemic stroke in humans. BMC Neurol 2013;13:178.

-33 Long G, Wang F, Duan Q, Yang S, Chen F, Gong W, Yang X, Wang Y, Chen C, Wang DW: Circulating miR-30a, miR-195 and let-7b associated with acute myocardial infarction. PLoS One 2012;7:e50926.

-34 Chen LW, Zhu LL, Ji Q, Zhu H, Ren YZ, Fan ZG, Li XB, Gao XF, Zhang YJ, Tian NL: [Relationship between myocardial microRNA-30a expression and myocardial fibrosis in rats post myocardial infarction]. Zhonghua Xin Xue Guan Bing Za Zhi 2016;44:443-449.

-35 Xie H, Lin HL, Wang N, Sun YL, Kan Y, Guo H, Chen JL, Fang M: Inhibition of microRNA-30a prevents puromycin aminonucleoside-induced podocytic apoptosis by upregulating the glucocorticoid receptor alpha. Mol Med Rep 2015;12:6043-6052.

-36 Kalluri R, Neilson EG: Epithelial-mesenchymal transition and its implications for fibrosis. J Clin Invest 2003;112:1776-1784.

37 Gheldof A, Berx G: Cadherins and epithelial-to-mesenchymal transition. Prog Mol Biol Transl Sci 2013;116:317-336.

- 38 Iwano M, Plieth D, Danoff TM, Xue C, Okada H, Neilson EG: Evidence that fibroblasts derive from epithelium during tissue fibrosis. J Clin Invest 2002;110:341-350.

-39 Kiemer AK, Takeuchi K, Quinlan MP: Identification of genes involved in epithelial-mesenchymal transition and tumor progression. Oncogene 2001;20:6679-6688.

40 Xue C, Plieth D, Venkov C, Xu C, Neilson EG: The gatekeeper effect of epithelial-mesenchymal transition regulates the frequency of breast cancer metastasis. Cancer Res 2003;63:3386-3394.

-41 Peng R, Zhou L, Zhou Y, Zhao Y, Li Q Ni D, Hu Y, Long Y, Liu J, Lyu Z, Mao Z, Yuan Y, Huang L, Zhao H, Li G, Zhou Q: MiR-30a Inhibits the Epithelial--Mesenchymal Transition of Podocytes through Downregulation of NFATc3. Int J Mol Sci 2015;16:24032-24047.

-42 Zhou Q, Yang M, Lan H, Yu X: miR-30a negatively regulates TGF-beta1-induced epithelial-mesenchymal transition and peritoneal fibrosis by targeting Snai1. Am J Pathol 2013;183:808-819.

43 He C, Klionsky DJ: Regulation mechanisms and signaling pathways of autophagy. Annu Rev Genet 2009;43:67-93.

44 Kumar S, Gupta P, Khanal S, Shahi A, Kumar P, Sarin SK, Venugopal SK: Overexpression of microRNA30a inhibits hepatitis B virus X protein-induced autophagosome formation in hepatic cells. FEBS J 2015;282:1152-1163.

45 Huang J, Huang C, Luo Y, Liu S, Chen X: Role of MiR-30a in cardiomyocyte autophagy induced by Angiotensin II. J Renin Angiotensin Aldosterone Syst 2015;16:1-5.

46 Pan W, Zhong Y, Cheng C, Liu B, Wang L, Li A, Xiong L, Liu S: MiR-30-regulated autophagy mediates angiotensin II-induced myocardial hypertrophy. PLoS One 2013;8:e53950.

47 Marchesi N, Osera C, Fassina L, Amadio M, Angeletti F, Morini M, Magenes G, Venturini L, Biggiogera M, Ricevuti G, Govoni S, Caorsi S, Pascale A, Comincini S: Autophagy is modulated in human neuroblastoma cells through direct exposition to low frequency electromagnetic fields. J Cell Physiol 2014;229:1776-1786. 


\section{Cellular Physiology Cell Physiol Biochem 2017;41:1616-1632

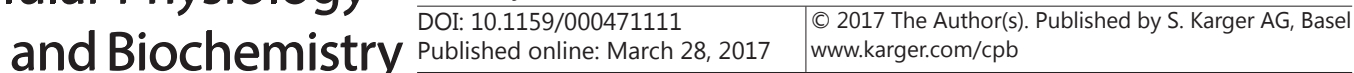

48 Xu K, Xu P, Yao JF, Zhang YG, Hou WK, Lu SM: Reduced apoptosis correlates with enhanced autophagy in synovial tissues of rheumatoid arthritis. Inflamm Res 2013;62:229-237.

49 Zhu H, Wu H, Liu X, Li B, Chen Y, Ren X, Liu CG, Yang JM: Regulation of autophagy by a beclin 1-targeted microRNA, miR-30a, in cancer cells. Autophagy 2009;5:816-823.

-50 Alsaleh G, Francois A, Philippe L, Gong YZ, Bahram S, Cetin S, Pfeffer S, Gottenberg JE, Wachsmann D, Georgel P, Sibilia J: MiR-30a-3p negatively regulates BAFF synthesis in systemic sclerosis and rheumatoid arthritis fibroblasts. PLoS One 2014;9:e111266.

-51 Wang Y, Li T, Wu B, Liu H, Luo J, Feng D, Shi Y: STAT1 regulates MD-2 expression in monocytes of sepsis via miR-30a. Inflammation 2014;37:1903-1911.

-52 Hu E, Ding L, Miao H, Liu F, Liu D, Dou H, Hou Y: MiR-30a attenuates immunosuppressive functions of IL1beta-elicited mesenchymal stem cells via targeting TAB3. FEBS Lett 2015;589:3899-3907.

53 Liu Y, Dong J, Mu R, Gao Y, Tan X, Li Y, Li Z, Yang G: MicroRNA-30a promotes B cell hyperactivity in patients with systemic lupus erythematosus by direct interaction with Lyn. Arthritis Rheum 2013;65:1603-1611.

-54 Darcq E, Warnault V, Phamluong K, Besserer GM, Liu F, Ron D: MicroRNA-30a-5p in the prefrontal cortex controls the transition from moderate to excessive alcohol consumption. Mol Psychiatry 2015;20:12191231.

55 Cai WY, Wei TZ, Luo QC, Wu QW, Liu QF, Yang M, Ye GD, Wu JF, Chen YY, Sun GB, Liu YJ, Zhao WX, Zhang ZM, Li BA: The Wnt-beta-catenin pathway represses let-7 microRNA expression through transactivation of Lin28 to augment breast cancer stem cell expansion. J Cell Sci 2013;126:2877-2889.

-56 Zhou AD, Diao LT, Xu H, Xiao ZD, Li JH, Zhou H, Qu LH: beta-Catenin/LEF1 transactivates the microRNA-371-373 cluster that modulates the Wnt/beta-catenin-signaling pathway. Oncogene 2012;31:2968-2978.

57 Ji Q, Xu X, Zhang Q Kang L, Xu Y, Zhang K, Li L, Liang Y, Hong T, Ye Q Wang Y: The IL-1beta/AP-1/miR30a/ADAMTS-5 axis regulates cartilage matrix degradation in human osteoarthritis. J Mol Med (Berl) 2016;94:771-785.

- 58 Zhang P, Yang X, Ma X, Ingram DR, Lazar AJ, Torres KE, Pollock RE: Antitumor effects of pharmacological EZH2 inhibition on malignant peripheral nerve sheath tumor through the miR-30a and KPNB1 pathway. Mol Cancer 2015;14:55.

-59 Liu Z, Chen L, Zhang X, Xu X, Xing H, Zhang Y, Li W, Yu H, Zeng J, Jia J: RUNX3 regulates vimentin expression via miR-30a during epithelial-mesenchymal transition in gastric cancer cells. J Cell Mol Med 2014;18:610623.

60 Croce N, Bernardini S, Caltagirone C, Angelucci F: Lithium/Valproic acid combination and L-glutamate induce similar pattern of changes in the expression of miR-30a-5p in SH-SY5Y neuroblastoma cells. Neuromolecular Med 2014;16:872-877.

61 Yu Y, Cao L, Yang L, Kang R, Lotze M, Tang D: microRNA 30A promotes autophagy in response to cancer therapy. Autophagy 2012;8:853-855.

-62 Zou Z, Wu L, Ding H, Wang Y, Zhang Y, Chen X, Chen X, Zhang CY, Zhang Q, Zen K: MicroRNA-30a sensitizes tumor cells to cis-platinum via suppressing beclin 1-mediated autophagy. J Biol Chem 2012;287:41484156.

-63 Rubio-Somoza I, Weigel D, Franco-Zorilla JM, Garcia JA, Paz-Ares J: ceRNAs: miRNA target mimic mimics. Cell 2011;147:1431-1432.

64 Liu K, Guo L, Guo Y, Zhou B, Li T, Yang H, Yin R, Xi T: AEG-1 3'-untranslated region functions as a ceRNA in inducing epithelial-mesenchymal transition of human non-small cell lung cancer by regulating miR-30a activity. Eur J Cell Biol 2015;94:22-31.

65 Chang TC, Yu D, Lee YS, Wentzel EA, Arking DE, West KM, Dang CV, Thomas-Tikhonenko A, Mendell JT: Widespread microRNA repression by Myc contributes to tumorigenesis. Nat Genet 2008;40:43-50.

-66 Ortega M, Bhatnagar H, Lin AP, Wang L, Aster JC, Sill H, Aguiar RC: A microRNA-mediated regulatory loop modulates NOTCH and MYC oncogenic signals in B- and T-cell malignancies. Leukemia 2015;29:968-976.

-67 Liu M, Huang F, Zhang D, Ju J, Wu XB, Wang Y, Wang Y, Wu Y, Nie M, Li Z, Ma C, Chen X, Zhou JY, Tan R, Yang BL, Zen K, Zhang CY, Chen YG, Zhao Q: Heterochromatin protein HP1gamma promotes colorectal cancer progression and is regulated by miR-30a. Cancer Res 2015;75:4593-4604.

-68 Wei W, Yang Y, Cai J, Cui K, Li RX, Wang H, Shang X, Wei D: MiR-30a-5p Suppresses Tumor Metastasis of Human Colorectal Cancer by Targeting ITGB3. Cell Physiol Biochem 2016;39:1165-1176. 


\section{Cellular Physiology Cell Physiol Biochem 2017;41:1616-1632

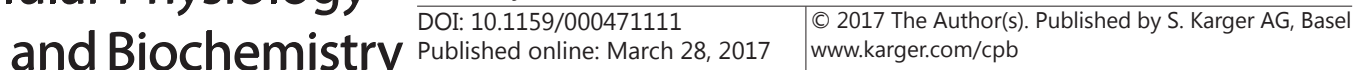

69 Huang WT, Chen ZX, He RQ, Wu YZ, Yin SY, Liang XN, Chen G, Yang H, Peng ZG, Yang LH: Clinicopathological role of miR-30a-5p in hepatocellular carcinoma tissues and prediction of its function with bioinformatics analysis. Onco Targets Ther 2016;9:5061-5071.

70 Wang W, Lin H, Zhou L, Zhu Q, Gao S, Xie H, Liu Z, Xu Z, Wei J, Huang X, Zheng S: MicroRNA-30a-3p inhibits tumor proliferation, invasiveness and metastasis and is downregulated in hepatocellular carcinoma. Eur J Surg Oncol 2014;40:1586-1594.

-71 Zeng RC, Zhang W, Yan XQ, Ye ZQ Chen ED, Huang DP, Zhang XH, Huang GL: Down-regulation of miRNA-30a in human plasma is a novel marker for breast cancer. Med Oncol 2013;30:477.

-72 Zheng B, Zhu H, Gu D, Pan X, Qian L, Xue B, Yang D, Zhou J, Shan Y: MiRNA-30a-mediated autophagy inhibition sensitizes renal cell carcinoma cells to sorafenib. Biochem Biophys Res Commun 2015;459:234239.

73 Lu N, Lin T, Wang L, Qi M, Liu Z, Dong H, Zhang X, Zhai C, Wang Y, Liu L, Xiang L, Qi L, Han B, Li J: Association of SOX4 regulated by tumor suppressor miR-30a with poor prognosis in low-grade chondrosarcoma. Tumour Biol 2015;36:3843-3852.

74 Wang Y, Li L, Qu Z, Li R, Bi T, Jiang J, Zhao H: The expression of miR-30a* and miR-30e* is associated with a dualistic model for grading ovarian papillary serious carcinoma. Int J Oncol 2014;44:1904-1914.

75 Boufraqech M, Nilubol N, Zhang L, Gara SK, Sadowski SM, Mehta A, He M, Davis S, Dreiling J, Copland JA, Smallridge RC, Quezado MM, Kebebew E: miR30a inhibits LOX expression and anaplastic thyroid cancer progression. Cancer Res 2015;75:367-377.

76 Zhang C, Ma X, Du J, Yao Z, Shi T, Ai Q Chen X, Zhang Z, Zhang X, Yao X: MicroRNA-30a as a prognostic factor in Urothelial Carcinoma of Bladder inhibits cellular malignancy by antagonizing Notch1. BJU Int DOI:10.1111/bju.13407.

77 Li C, Zou J, Zheng G, Chu J: MiR-30a Decreases Multidrug Resistance (MDR) of Gastric Cancer Cells. Med Sci Monit 2016;0:0.

-78 Wang LL, Zhang XH, Zhang X, Chu JK: MiR-30a increases cisplatin sensitivity of gastric cancer cells through suppressing epithelial-to-mesenchymal transition (EMT). Eur Rev Med Pharmacol Sci 2016;20:1733-1739.

79 Zhang J, Shen C, Wang L, Ma Q, Xia P, Qi M, Yang M, Han B: Metformin inhibits epithelial-mesenchymal transition in prostate cancer cells: involvement of the tumor suppressor miR30a and its target gene SOX4. Biochem Biophys Res Commun 2014;452:746-752.

-80 Wang K, Jia Z, Zou J, Zhang A, Wang G, Hao J, Wang Y, Yang S, Pu P: Analysis of hsa-miR-30a-5p expression in human gliomas. Pathol Oncol Res 2013;19:405-411.

81 Zhou J, Gong G, Tan H, Dai F, Zhu X, Chen Y, Wang J, Liu Y, Chen P, Wu X, Wen J: Urinary microRNA-30a-5p is a potential biomarker for ovarian serous adenocarcinoma. Oncol Rep 2015;33:2915-2923.

82 Ferlay J, Soerjomataram I, Dikshit R, Eser S, Mathers C, Rebelo M, Parkin DM, Forman D, Bray F: Cancer incidence and mortality worldwide: sources, methods and major patterns in GLOBOCAN 2012. Int J Cancer 2015;136:E359-386.

83 Hirsch FR, Scagliotti GV, Mulshine JL, Kwon R, Curran WJ, Jr., Wu YL, Paz-Ares L: Lung cancer: current therapies and new targeted treatments. Lancet 2017;389:299-311.

-84 Wen XP, Ma HL, Zhao LY, Zhang W, Dang CX: MiR-30a suppresses non-small cell lung cancer progression through AKT signaling pathway by targeting IGF1R. Cell Mol Biol (Noisy-le-grand) 2015;61:78-85.

-85 Jiang BY, Zhang XC, Su J, Meng W, Yang XN, Yang JJ, Zhou Q, Chen ZY, Chen ZH, Xie Z, Chen SL, Wu YL: BCL11A overexpression predicts survival and relapse in non-small cell lung cancer and is modulated by microRNA-30a and gene amplification. Mol Cancer 2013;12:61.

-86 Kumarswamy R, Mudduluru G, Ceppi P, Muppala S, Kozlowski M, Niklinski J, Papotti M, Allgayer H: MicroRNA-30a inhibits epithelial-to-mesenchymal transition by targeting Snai1 and is downregulated in non-small cell lung cancer. Int J Cancer 2012;130:2044-2053.

87 Torre LA, Bray F, Siegel RL, Ferlay J, Lortet-Tieulent J, Jemal A: Global cancer statistics, 2012. CA Cancer J Clin 2015;65:87-108.

88 Fu J, Xu X, Kang L, Zhou L, Wang S, Lu J, Cheng L, Fan Z, Yuan B, Tian P, Zheng X, Yu C, Ye Q, Lv Z: miR30a suppresses breast cancer cell proliferation and migration by targeting Eya2. Biochem Biophys Res Commun 2014;445:314-319.

89 Cheng CW, Wang HW, Chang CW, Chu HW, Chen CY, Yu JC, Chao JI, Liu HF, Ding SL, Shen CY: MicroRNA-30a inhibits cell migration and invasion by downregulating vimentin expression and is a potential prognostic marker in breast cancer. Breast Cancer Res Treat 2012;134:1081-1093. 


\section{Cellular Physiology Cell Physiol Biochem 2017;41:1616-1632

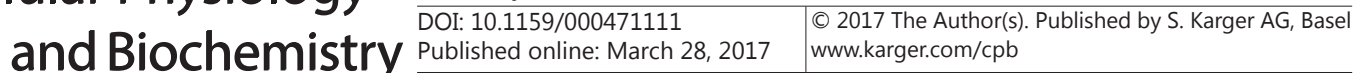

90 Chang CW, Yu JC, Hsieh YH, Yao CC, Chao JI, Chen PM, Hsieh HY, Hsiung CN, Chu HW, Shen CY, Cheng CW: MicroRNA-30a increases tight junction protein expression to suppress the epithelial-mesenchymal transition and metastasis by targeting Slug in breast cancer. Oncotarget 2016;7:16462-16478.

$\$ 91$ Baraniskin A, Birkenkamp-Demtroder K, Maghnouj A, Zollner H, Munding J, Klein-Scory S, Reinacher-Schick A, Schwarte-Waldhoff I, Schmiegel W, Hahn SA: MiR-30a-5p suppresses tumor growth in colon carcinoma by targeting DTL. Carcinogenesis 2012;33:732-739.

-92 Liu L, Meng T, Wang QS, Jin HZ, Sun ZQ Jin B, Fang F, Wang HJ: Association of Beclin-1 and microRNA-30a expression with the severity and treatment response of colorectal cancer. Genet Mol Res 2016;15.

-93 Zhang Q, Tang Q, Qin D, Yu L, Huang R, Lv G, Zou Z, Jiang XC, Zou C, Liu W, Luo J, Zhao Z, Muhammad S, Wang G, Chen YG, Wang X: Role of microRNA 30a targeting insulin receptor substrate 2 in colorectal tumorigenesis. Mol Cell Biol 2015;35:988-1000.

-94 Zhong M, Bian Z, Wu Z: miR-30a suppresses cell migration and invasion through downregulation of PIK3CD in colorectal carcinoma. Cell Physiol Biochem 2013;31:209-218.

-95 Jemal A, Bray F, Center MM, Ferlay J, Ward E, Forman D: Global cancer statistics. CA Cancer J Clin 2011;61:69-90.

-96 Nguyen DX, Bos PD, Massague J: Metastasis: from dissemination to organ-specific colonization. Nat Rev Cancer 2009;9:274-284.

97 Liu Z, Tu K, Liu Q: Effects of microRNA-30a on migration, invasion and prognosis of hepatocellular carcinoma. FEBS Lett 2014;588:3089-3097.

-98 Li WF, Dai H, Ou Q Zuo GQ Liu CA: Overexpression of microRNA-30a-5p inhibits liver cancer cell proliferation and induces apoptosis by targeting MTDH/PTEN/AKT pathway. Tumour Biol 2016;37:58855895.

99 Furnari FB, Fenton T, Bachoo RM, Mukasa A, Stommel JM, Stegh A, Hahn WC, Ligon KL, Louis DN, Brennan C, Chin L, DePinho RA, Cavenee WK: Malignant astrocytic glioma: genetics, biology, and paths to treatment. Genes Dev 2007;21:2683-2710.

100 Che S, Sun T, Wang J, Jiao Y, Wang C, Meng Q, Qi W, Yan Z: miR-30 overexpression promotes glioma stem cells by regulating Jak/STAT3 signaling pathway. Tumour Biol 2015;36:6805-6811.

101 Jia Z, Wang K, Wang G, Zhang A, Pu P: MiR-30a-5p antisense oligonucleotide suppresses glioma cell growth by targeting SEPT7. PLoS One 2013;8:e55008.

102 Bovee JV, Hogendoorn PC, Wunder JS, Alman BA: Cartilage tumours and bone development: molecular pathology and possible therapeutic targets. Nat Rev Cancer 2010;10:481-488.

103 Franzetti GA, Laud-Duval K, Bellanger D, Stern MH, Sastre-Garau X, Delattre O: MiR-30a-5p connects EWSFLI1 and CD99, two major therapeutic targets in Ewing tumor. Oncogene 2013;32:3915-3921.

104 Fuster O, Llop M, Dolz S, Garcia P, Such E, Ibanez M, Luna I, Gomez I, Lopez M, Cervera J, Montesinos P, Moscardo F, Cordon L, Solves P, de Juan I, Palanca S, Bolufer P, Sanz MA, Barragan E: Adverse prognostic value of MYBL2 overexpression and association with microRNA-30 family in acute myeloid leukemia patients. Leuk Res 2013;37:1690-1696.

105 Liu Y, Song Y, Ma W, Zheng W, Yin H: Decreased microRNA-30a levels are associated with enhanced ABL1 and BCR-ABL1 expression in chronic myeloid leukemia. Leuk Res 2013;37:349-356.

106 Wang HY, Li YY, Fu S, Wang XP, Huang MY, Zhang X, Shao Q, Deng L, Zeng MS, Zeng YX, Shao JY: MicroRNA30 a promotes invasiveness and metastasis in vitro and in vivo through epithelial-mesenchymal transition and results in poor survival of nasopharyngeal carcinoma patients. Exp Biol Med (Maywood) 2014;239:891-898.

107 Wang R, Li H, Guo X, Wang Z, Liang S, Dang C: IGF-I Induces Epithelial-to-Mesenchymal Transition via the IGF-IR-Src-MicroRNA-30a-E-Cadherin Pathway in Nasopharyngeal Carcinoma Cells. Oncol Res 2016;24:225-231.

108 Zaragosi LE, Wdziekonski B, Brigand KL, Villageois P, Mari B, Waldmann R, Dani C, Barbry P: Small RNA sequencing reveals miR-642a-3p as a novel adipocyte-specific microRNA and miR-30 as a key regulator of human adipogenesis. Genome Biol 2011;12:R64.

109 Huang Q Jiang Z, Meng T, Yin H, Wang J, Wan W, Cheng M, Yan W, Liu T, Song D, Chen H, Wu Z, Xu W, Li Z, Zhou W, Xiao J: MiR-30a inhibits osteolysis by targeting RunX2 in giant cell tumor of bone. Biochem Biophys Res Commun 2014;453:160-165.

110 Liao Y, Lv G, Wang B, Kuang L, Wang X: Imatinib promotes apoptosis of giant cell tumor cells by targeting microRNA-30a-mediated runt-related transcription factor 2. Mol Med Rep 2016;13:1739-1745. 


\section{Cellular Physiology Cell Physiol Biochem 2017;41:1616-1632 and Biochemistry \begin{tabular}{l|l} 
DOI: 10.1159/000471111 & $\begin{array}{l}\text { (c) } 2017 \text { The Author(s). Published by S. Karger AG, Basel } \\
\text { www.karger.com/cpb }\end{array}$
\end{tabular}

111 Zhao JJ, Lin J, Zhu D, Wang X, Brooks D, Chen M, Chu ZB, Takada K, Ciccarelli B, Admin S, Tao J, Tai YT, Treon S, Pinkus G, Kuo WP, Hideshima T, Bouxsein M, Munshi N, Anderson K, Carrasco R: miR-30-5p functions as a tumor suppressor and novel therapeutic tool by targeting the oncogenic Wnt/beta-catenin/BCL9 pathway. Cancer Res 2014;74:1801-1813.

112 Xie T, Huang M, Wang Y, Wang L, Chen C, Chu X: MicroRNAs as Regulators, Biomarkers and Therapeutic Targets in the Drug Resistance of Colorectal Cancer. Cell Physiol Biochem 2016;40:62-76.

113 Chen Y, Gao Y, Zhang K, Li C, Pan Y, Chen J, Wang R, Chen L: MicroRNAs as Regulators of Cisplatin Resistance in Lung Cancer. Cell Physiol Biochem 2015;37:1869-1880.

114 Wu ZB, Li WQ Lin SJ, Wang CD, Cai L, Lu JL, Chen YX, Su ZP, Shang HB, Yang WL, Zhao WG: MicroRNA expression profile of bromocriptine-resistant prolactinomas. Mol Cell Endocrinol 2014;395:10-18.

115 Meng F, Wang F, Wang L, Wong SC, Cho WC, Chan LW: MiR-30a-5p Overexpression May Overcome EGFRInhibitor Resistance through Regulating PI3K/AKT Signaling Pathway in Non-small Cell Lung Cancer Cell Lines. Front Genet 2016;7:197.

116 Yu Y, Yang L, Zhao M, Zhu S, Kang R, Vernon P, Tang D, Cao L: Targeting microRNA-30a-mediated autophagy enhances imatinib activity against human chronic myeloid leukemia cells. Leukemia 2012;26:1752-1760.

-117 Liu J, Wu X, Liu H, Liang Y, Gao X, Cai Z, Wang W, Zhang H: Expression of microRNA-30a-5p in drug-resistant and drug-sensitive ovarian cancer cell lines. Oncol Lett 2016;12:2065-2070.

118 Chen N, Chon HS, Xiong Y, Marchion DC, Judson PL, Hakam A, Gonzalez-Bosquet J, Permuth-Wey J, Wenham RM, Apte SM, Cheng JQ Sellers TA, Lancaster JM: Human cancer cell line microRNAs associated with in vitro sensitivity to paclitaxel. Oncol Rep 2014;31:376-383.

119 Wang J, Jiao Y, Cui L, Jiang L: miR-30 functions as an oncomiR in gastric cancer cells through regulation of P53-mediated mitochondrial apoptotic pathway. Biosci Biotechnol Biochem 2017;81:119-126.

120 Moreno-Mateos MA, Barragan V, Torres B, Rodriguez-Mateo C, Mendez-Vidal C, Berezikov E, Mudduluru G, Allgayer H, Pintor-Toro JA: Novel small RNA expression libraries uncover hsa-miR-30b and hsa-miR-30c as important factors in anoikis resistance. Rna 2013;19:1711-1725.

121 Yang RF, Chen LJ, Li JY, Li CM, Xu JR, Wu YJ, Lu H: [microRNA-21 and microRNA-30b expression in multiple myeloma.]. Zhonghua Xue Ye Xue Za Zhi 2010;31:38-41.

122 Tsukasa K, Ding Q, Miyazaki Y, Matsubara S, Natsugoe S, Takao S: miR-30 family promotes migratory and invasive abilities in CD133(+) pancreatic cancer stem-like cells. Hum Cell 2016;29:130-137.

123 Zhang S, Guo LJ, Zhang G, Wang LL, Hao S, Gao B, Jiang Y, Tian WG, Cao XE, Luo DL: Roles of microRNA-124a and microRNA-30d in breast cancer patients with type 2 diabetes mellitus. Tumour Biol 2016;37:1105711063.

124 Lu Y, Ryan SL, Elliott DJ, Bignell GR, Futreal PA, Ellison DW, Bailey S, Clifford SC: Amplification and overexpression of Hsa-miR-30b, Hsa-miR-30d and KHDRBS3 at 8q24.22-q24.23 in medulloblastoma. PLoS One 2009;4:e6159.

125 Lin Z, Li JW, Wang Y, Chen T, Ren N, Yang L, Xu W, He H, Jiang Y, Chen X, Liu T, Liu G: Abnormal miRNA-30e Expression is Associated with Breast Cancer Progression. Clin Lab 2016;62:121-128.

126 Yang X, Zhong X, Tanyi JL, Shen J, Xu C, Gao P, Zheng TM, DeMichele A, Zhang L: mir-30d Regulates multiple genes in the autophagy pathway and impairs autophagy process in human cancer cells. Biochem Biophys Res Commun 2013;431:617-622.

127 Liao WT, Ye YP, Zhang NJ, Li TT, Wang SY, Cui YM, Qi L, Wu P, Jiao HL, Xie YJ, Zhang C, Wang JX, Ding YQ: MicroRNA-30b functions as a tumour suppressor in human colorectal cancer by targeting KRAS, PIK3CD and BCL2. J Pathol 2014;232:415-427.

128 Gu YF, Zhang H, Su D, Mo ML, Song P, Zhang F, Zhang SC: miR-30b and miR-30c expression predicted response to tyrosine kinase inhibitors as first line treatment in non-small cell lung cancer. Chin Med J (Engl) 2013;126:4435-4439.

129 Bhattacharya S, Steele R, Shrivastava S, Chakraborty S, Di Bisceglie AM, Ray RB: Serum miR-30e and miR223 as Novel Noninvasive Biomarkers for Hepatocellular Carcinoma. Am J Pathol 2016;186:242-247.

130 D'Aiuto F, Callari M, Dugo M, Merlino G, Musella V, Miodini P, Paolini B, Cappelletti V, Daidone MG: miR-30e* is an independent subtype-specific prognostic marker in breast cancer. Br J Cancer 2015;113:290-298.

131 Markou A, Sourvinou I, Vorkas PA, Yousef GM, Lianidou E: Clinical evaluation of microRNA expression profiling in non small cell lung cancer. Lung Cancer 2013;81:388-396. 


\section{Cellular Physiology Cell Physiol Biochem 2017;41:1616-1632 \begin{tabular}{l|l} 
and Biochemistry & DOI: 10.1159/000471111 2017 The Author(s). Published by S. Karger AG, Basel \\
(c) 2017 & www.karger.com/cpb
\end{tabular}

132 Li N, Kaur S, Greshock J, Lassus H, Zhong X, Wang Y, Leminen A, Shao Z, Hu X, Liang S, Katsaros D, Huang Q, Butzow R, Weber BL, Coukos G, Zhang L: A combined array-based comparative genomic hybridization and functional library screening approach identifies mir-30d as an oncomir in cancer. Cancer Res 2012;72:154164.

133 Hershkovitz-Rokah O, Modai S, Pasmanik-Chor M, Toren A, Shomron N, Raanani P, Shpilberg O, Granot G: MiR-30e induces apoptosis and sensitizes K562 cells to imatinib treatment via regulation of the BCR-ABL protein. Cancer Lett 2015;356:597-605.

134 Zhang Y, Yang WQ Zhu H, Qian YY, Zhou L, Ren YJ, Ren XC, Zhang L, Liu XP, Liu CG, Ming ZJ, Li B, Chen B, Wang JR, Liu YB, Yang JM: Regulation of autophagy by miR-30d impacts sensitivity of anaplastic thyroid carcinoma to cisplatin. Biochem Pharmacol 2014;87:562-570.

135 Su SF, Chang YW, Andreu-Vieyra C, Fang JY, Yang Z, Han B, Lee AS, Liang G: miR-30d, miR-181a and miR199a-5p cooperatively suppress the endoplasmic reticulum chaperone and signaling regulator GRP78 in cancer. Oncogene 2013;32:4694-4701.

136 Ning ZQ, Lu HL, Chen C, Wang L, Cai W, Li Y, Cao TH, Zhu J, Shu YQ, Shen H: MicroRNA-30e reduces cell growth and enhances drug sensitivity to gefitinib in lung carcinoma. Oncotarget DOI:10.18632/ oncotarget.13944.

137 Chen S, Li P, Yang R, Cheng R, Zhang F, Wang Y, Chen X, Sun Q, Zang W, Du Y, Zhao G, Zhang G: microRNA-30b inhibits cell invasion and migration through targeting collagen triple helix repeat containing 1 in non-small cell lung cancer. Cancer Cell Int 2015;15:85.

138 Zhong K, Chen K, Han L, Li B: MicroRNA-30b/c inhibits non-small cell lung cancer cell proliferation by targeting Rab18. BMC Cancer 2014;14:703.

139 Ren X, Wang C, Xie B, Hu L, Chai H, Ding L, Tang L, Xia Y, Dou X: Tanshinone IIA induced cell death via miR30b-p53-PTPN11/SHP2 signaling pathway in human hepatocellular carcinoma cells. Eur J Pharmacol DOI:10.1016/j.ejphar.2016.11.046.

140 Sun X, Zhao S, Li H, Chang H, Huang Z, Ding Z, Dong L, Chen J, Zang Y, Zhang J: MicroRNA-30b Suppresses Epithelial-Mesenchymal Transition and Metastasis of Hepatoma Cells. J Cell Physiol 2017;232:625-634.

141 Kumar B, Khaleghzadegan S, Mears B, Hatano K, Kudrolli TA, Chowdhury WH, Yeater DB, Ewing CM, Luo J, Isaacs WB, Marchionni L, Lupold SE: Identification of miR-30b-3p and miR-30d-5p as direct regulators of Androgen Receptor Signaling in Prostate Cancer by complementary functional microRNA library screening. Oncotarget DOI:10.18632/oncotarget.12241.

142 Tian SB, Yu JC, Liu YQ, Kang WM, Ma ZQ Ye X, Yan C: MiR-30b suppresses tumor migration and invasion by targeting EIF5A2 in gastric cancer. World J Gastroenterol 2015;21:9337-9347.

143 Zhu ED, Li N, Li BS, Li W, Zhang WJ, Mao XH, Guo G, Zou QM, Xiao B: miR-30b, down-regulated in gastric cancer, promotes apoptosis and suppresses tumor growth by targeting plasminogen activator inhibitor-1. PLoS One 2014;9:e106049.

144 Qiao F, Zhang K, Gong P, Wang L, Hu J, Lu S, Fan H: Decreased miR-30b-5p expression by DNMT1 methylation regulation involved in gastric cancer metastasis. Mol Biol Rep 2014;41:5693-5700.

145 Zhao H, Xu Z, Qin H, Gao Z, Gao L: miR-30b regulates migration and invasion of human colorectal cancer via SIX1. Biochem J 2014;460:117-125.

146 Li L, Wang B: Overexpression of microRNA-30b improves adenovirus-mediated p53 cancer gene therapy for laryngeal carcinoma. Int J Mol Sci 2014;15:19729-19740.

147 Quintavalle C, Donnarumma E, Iaboni M, Roscigno G, Garofalo M, Romano G, Fiore D, De Marinis P, Croce CM, Condorelli G: Effect of miR-21 and miR-30b/c on TRAIL-induced apoptosis in glioma cells. Oncogene 2013;32:4001-4008.

148 Ichikawa T, Sato F, Terasawa K, Tsuchiya S, Toi M, Tsujimoto G, Shimizu K: Trastuzumab produces therapeutic actions by upregulating miR-26a and miR-30b in breast cancer cells. PLoS One 2012; 7:e31422.

149 Gaziel-Sovran A, Segura MF, Di Micco R, Collins MK, Hanniford D, Vega-Saenz de Miera E, Rakus JF, Dankert JF, Shang S, Kerbel RS, Bhardwaj N, Shao Y, Darvishian F, Zavadil J, Erlebacher A, Mahal LK, Osman I, Hernando E: miR-30b/30d regulation of GalNAc transferases enhances invasion and immunosuppression during metastasis. Cancer Cell 2011;20:104-118.

150 Zhong Z, Xia Y, Wang P, Liu B, Chen Y: Low expression of microRNA-30c promotes invasion by inducing epithelial mesenchymal transition in non-small cell lung cancer. Mol Med Rep 2014;10:2575-2579. 


\section{Cellular Physiology Cell Physiol Biochem 2017;41:1616-1632

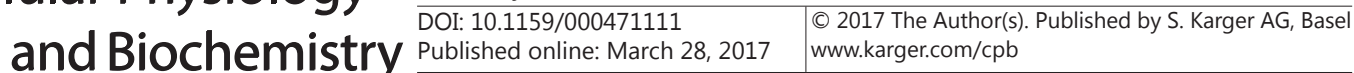

151 Agostini A, Brunetti M, Davidson B, Trope CG, Heim S, Panagopoulos I, Micci F: Expressions of miR-30c and let-7a are inversely correlated with HMGA2 expression in squamous cell carcinoma of the vulva. Oncotarget 2016;7:85058-85062.

152 Dobson JR, Taipaleenmaki H, Hu YJ, Hong D, van Wijnen AJ, Stein JL, Stein GS, Lian JB, Pratap J: hsa-mir-30c promotes the invasive phenotype of metastatic breast cancer cells by targeting NOV/CCN3. Cancer Cell Int 2014;14:73.

153 Chen D, Guo W, Qiu Z, Wang Q Li Y, Liang L, Liu L, Huang S, Zhao Y, He X: MicroRNA-30d-5p inhibits tumour cell proliferation and motility by directly targeting CCNE2 in non-small cell lung cancer. Cancer Lett 2015;362:208-217.

154 Yao J, Liang L, Huang S, Ding J, Tan N, Zhao Y, Yan M, Ge C, Zhang Z, Chen T, Wan D, Yao M, Li J, Gu J, He X: MicroRNA-30d promotes tumor invasion and metastasis by targeting Galphai2 in hepatocellular carcinoma. Hepatology 2010;51:846-856.

155 Xuan H, Xue W, Pan J, Sha J, Dong B, Huang Y: Downregulation of miR-221, -30d, and -15a contributes to pathogenesis of prostate cancer by targeting Bmi-1. Biochemistry (Mosc) 2015;80:276-283.

156 Kobayashi N, Uemura H, Nagahama K, Okudela K, Furuya M, Ino Y, Ito Y, Hirano H, Inayama Y, Aoki I, Nagashima Y, Kubota Y, Ishiguro H: Identification of miR-30d as a novel prognostic maker of prostate cancer. Oncotarget 2012;3:1455-1471.

157 Ye Z, Zhao L, Li J, Chen W, Li X: miR-30d Blocked Transforming Growth Factor beta1-Induced EpithelialMesenchymal Transition by Targeting Snail in Ovarian Cancer Cells. Int J Gynecol Cancer 2015;25:15741581.

158 Ye Z, Li J, Han X, Hou H, Chen H, Zheng X, Lu J, Wang L, Chen W, Li X, Zhao L: TET3 inhibits TGF-beta1induced epithelial-mesenchymal transition by demethylating miR-30d precursor gene in ovarian cancer cells. J Exp Clin Cancer Res 2016;35:72.

159 Yu H, Lin X, Wang F, Zhang B, Wang W, Shi H, Zou B, Zhao J: Proliferation inhibition and the underlying molecular mechanisms of microRNA-30d in renal carcinoma cells. Oncol Lett 2014;7:799-804.

160 Wu C, Jin B, Chen L, Zhuo D, Zhang Z, Gong K, Mao Z: MiR-30d induces apoptosis and is regulated by the Akt/FOXO pathway in renal cell carcinoma. Cell Signal 2013;25:1212-1221.

161 Esposito F, Tornincasa M, Pallante P, Federico A, Borbone E, Pierantoni GM, Fusco A: Down-regulation of the miR-25 and miR-30d contributes to the development of anaplastic thyroid carcinoma targeting the polycomb protein EZH2. J Clin Endocrinol Metab 2012;97:E710-718.

162 Zhang P, Garnett J, Creighton CJ, Al Sannaa GA, Igram DR, Lazar A, Liu X, Liu C, Pollock RE: EZH2-miR-30dKPNB1 pathway regulates malignant peripheral nerve sheath tumour cell survival and tumourigenesis. J Pathol 2014;232:308-318.

163 Chakrabarti M, Klionsky DJ, Ray SK: miR-30e Blocks Autophagy and Acts Synergistically with Proanthocyanidin for Inhibition of AVEN and BIRC6 to Increase Apoptosis in Glioblastoma Stem Cells and Glioblastoma SNB19 Cells. PLoS One 2016;11:e0158537.

164 Kwak SY, Kim BY, Ahn HJ, Yoo JO, Kim J, Bae IH, Han YH: Ionizing radiation-inducible miR-30e promotes glioma cell invasion through EGFR stabilization by directly targeting CBL-B. FEBS J 2015;282:1512-1525.

165 Jiang L, Lin C, Song L, Wu J, Chen B, Ying Z, Fang L, Yan X, He M, Li J, Li M: MicroRNA-30e* promotes human glioma cell invasiveness in an orthotopic xenotransplantation model by disrupting the NF-kappaB/ IkappaBalpha negative feedback loop. J Clin Invest 2012;122:33-47.

166 Ye Y, Fang Y, Xu W, Wang Q Zhou J, Lu R: 3,3'-Diindolylmethane induces anti-human gastric cancer cells by the miR-30e-ATG5 modulating autophagy. Biochem Pharmacol 2016;115:77-84.

167 Sugihara H, Ishimoto T, Watanabe M, Sawayama H, Iwatsuki M, Baba Y, Komohara Y, Takeya M, Baba H: Identification of miR-30 $\mathrm{e}^{*}$ regulation of Bmi1 expression mediated by tumor-associated macrophages in gastrointestinal cancer. PLoS One 2013;8:e81839.

168 Feng G, Shi H, Li J, Yang Z, Fang R, Ye L, Zhang W, Zhang X: MiR-30e suppresses proliferation of hepatoma cells via targeting prolyl 4-hydroxylase subunit alpha-1 (P4HA1) mRNA. Biochem Biophys Res Commun 2016;472:516-522.

169 Sohn D, Peters D, Piekorz RP, Budach W, Janicke RU: miR-30e controls DNA damage-induced stress responses by modulating expression of the CDK inhibitor p21WAF1/CIP1 and caspase-3. Oncotarget 2016;7:15915-15929. 